\title{
Notch signals in the endothelium and cancer "stem-like" cells: opportunities for cancer therapy
}

\author{
Vascular Cell 4:7 | DOI: 10.1186/2045-824X-4-7 I C Li et al.; licensee Publiverse Online S.R.L. 2012 \\ Received: 17 Jan 2012 | Accepted: 9 Jan 2012 | Published: 9 Jan 2012 \\ Gu Jian-Wei, Rizzo Paola, Pannuti Antonio, Golde Todd, Osborne Barbara, Miele Lucio ${ }^{\circledR}$ \\ ${ }^{+}$Contributed equally ${ }^{\circledR}$ Corresponding author
}

\section{Abstract}

Anti-angiogenesis agents and the identification of cancer stem-like cells (CSC) are opening new avenues for targeted cancer therapy. Recent evidence indicates that angiogenesis regulatory pathways and developmental pathways that control CSC fate are intimately connected, and that endothelial cells are a key component of the CSC niche. Numerous anti-angiogenic therapies developed so far target the VEGF pathway. However, VEGFtargeted therapy is hindered by clinical resistance and side effects, and new approaches are needed. One such approach may be direct targeting of tumor endothelial cell fate determination. Interfering with tumor endothelial cells growth and survival could inhibit not only angiogenesis but also the self-replication of CSC, which relies on signals from surrounding endothelial cells in the tumor microenvironment. The Notch pathway is central to controlling cell fate both during angiogenesis and in CSC from several tumors. A number of investigational Notch inhibitors are being developed. Understanding how Notch interacts with other factors that control endothelial cell functions and angiogenesis in cancers could pave the way to innovative therapeutic strategies that simultaneously target angiogenesis and CSC.

\section{Introduction}

The endothelium is a key regulator of vascular integrity and function. Endothelial cell functions and gene expression profiles are controlled by cytokines, hormones and metabolic products, as well as by mechanical stimuli such as shear stress caused by changes in blood flow [1]. Endothelial cells play a major role in the creation of supplemental blood vessels in ischemic tissues following vascular obstruction. This process is "hijacked" by cancer, which depends on neo-angiogenesis and vasculogenesis for growth and invasion.

Endothelial cells are also an important component of the "vascular niche" for cancer stem-like cells (CSC) [ 2]. A number of pathways, including vascular endothelial growth factor (VEGF) and its receptors (VEGFRs), basic fibroblast growth factor (bFGF), transforming growth factor beta (TGF $\beta$ ), and platelet-derived growth factor (PDGF) with their receptors, angiopoietin/Tie and ephrin/Eph, regulate vasculogenesis and angiogenesis [ 3]. Notch signaling, directly or by cross-talking with other pathways, plays a major role in modulating endothelial cells functions [ 4]. Additionally, Notch signaling has emerged as one of the master pathways in CSC [ 5]. This review summarizes the current data on the effects of Notch signaling in endothelial cells and CSC and how this modulation can be exploited for therapeutic purposes.

\section{The Notch pathway}

Notch signaling is a highly conserved pathway that controls cell fate decisions in metazoans from invertebrates to mammals $[6,7]$. It is a short range communication system between two adjacent cells, based on ligandactivated receptors. In mammals there are four paralog receptors (Notch1, $-2,-3$ and -4) and five canonical ligands (Delta-like or DLL1, 3, 4 and Jagged1 and 2). Both receptors and ligands are type I membranespanning proteins Receptors are heterodimers consisting of an extracellular subunit $\left(\mathrm{N}^{\mathrm{EC}}\right)$ non-covalently bound to a transmembrane subunit $\left(\mathrm{N}^{\mathrm{TM}}\right)$. Both subunits derive from a single precursor that is cleaved in the trans-Golgi by a furin-like protease. Ligand binding to $\mathrm{N}^{\mathrm{EC}}$ induces a conformational change that allows subunit dissociation. This is followed by the first proteolytic cut by a surface protease ADAM (A Disintegrin 
And Metalloprotease) which removes a short extracellular fragment of $\mathrm{N}^{\mathrm{TM}}$ and creates a membrane-tethered intermediate (Notch extracellular truncation or NEXT). NEXT is a substrate for $\gamma$-secretase, an intramembranous protease complex. $\gamma$-Secretase in turn generates the active form of Notch (Notch intracellular, $\mathrm{N}^{\mathrm{IC}}$ ) which translocates to the nucleus where it binds transcription factor CSL ( CBF-1, Suppressor of Hairless, Lag-1), also known as RPB-J (recombinant signal binding protein $1 \mathrm{for} J \varkappa$ ) in mice. $\mathrm{N}^{\mathrm{IC}}$ binding displaces a co-repressor complex, promotes the recruitment of co-activator molecules and the transcription of numerous Notch target genes (Figure 1). The best known Notch targets include the Hes (hairy/enhancer of split) and Hey (Hes-related proteins) families and Nrarp (Notch-regulated ankyrin repeat protein). These and other Notch targets regulate further downstream genes which can either maintain cell in an uncommitted state or induce differentiation. The mechanistic reasons for these differences remain unclear. Cyclin D1, cMyc, and many other genes that control cell proliferation, differentiation and apoptosis are also influenced by Notch [ 8]. Although this pathway appears deceptively simple and is theoretically identical for all 4 Notch paralogs, exceedingly complex mechanisms regulate Notch signal intensity and paralog-specific effects. These are described in our recent review [ 5], and summarized diagrammatically in Figure 1. In addition to embryonic development, the Notch pathway controls multiple cell fate decisions during adult life, including stem cells maintenance, differentiation and proliferation as well as apoptosis in continuously renewing tissues such as the epidermis, the intestinal epithelium and the endothelium. Figure 1

A simplified diagram of canonical Notch signaling: A: membrane and cytoplasmic events. In ligand expressing cells, ligands are ubiquitinated (UQ) by E3 ligases Mindbomb and Neuralized, endocytosed and "activated". "Active" ligands bind Notch receptors, dissociating $\mathrm{N}^{\mathrm{EC}}$ from $\mathrm{N}^{\mathrm{TM}}$. The complex ligand- $\mathrm{N}^{\mathrm{EC}}$ is transendocytosed into the ligand-expressing cell, perhaps providing mechanical energy to separate $\mathrm{N}^{\mathrm{EC}}$ from $\mathrm{N}^{\mathrm{TM}}$. Some ligands expressed in cis can bind Notch on the same cell, causing cis-inhibition. Ligand-induced N $\mathrm{EC}$ separation unmasks the ADAM cleavage site (red), which is cleaved by ADAM10 or ADAM17, producing $\mathrm{N}^{\mathrm{EXT}}$ and a short peptide which is released. $\mathrm{N}^{\mathrm{EXT}}$ is cleaved by $\gamma$-secretase, at the membrane or during endocytosis, generating $\mathrm{N}^{\mathrm{IC}}$. This process is facilitated by adaptor-associated kinase AAK1 [101] and may require mono-ubiquitination. The release of $\mathrm{N}^{\mathrm{IC}}$ from endosomes (or the selection of cleavage site by $\gamma$ secretase) may require endosome acidification $\left(\mathrm{H}^{+}\right)$by aquaporin $\mathrm{Bib}$. The stability of $\mathrm{N}^{\mathrm{IC}}$ is regulated by factors such as Pin-1 prolyl isomerase and NLK kinase. Endocytosis can lead to ligand-independent Notch activation catalyzed by $\gamma$-secretase. In the absence of non-visual $\beta$-arrestin Kurz, Deltex may lead to Notch endocytosis and activation. The amount of Notch available at the membrane is controlled by many endocytosis-recycling mechanisms. Several E3 ligases (Itch, CBL, Nedd4, the Deltex-Kurz complex) can target Notch for degradation. The ESCRT complex and lgd in Drosophila (and presumably their homologues in mammals) control Notch degradation, and their loss causes accumulation of Notch in endosomes and ligandindependent activation. In actively dividing cells, Numb/ACBD3 asymmetrically partitions to one daughter cell, causing selective Notch degradation in it. GSI, monoclonal antibodies (mAbs) to Notch receptors and ligands and Notch decoy molecules have been used effectively in vivo to inhibit Notch signaling. B: nuclear events. $\mathrm{N}^{\mathrm{IC}}$ is transported to the nucleus, where it causes the dissociation of the co-repressor complex including SHARP, SKIP and several other proteins (CoR) from CSL. Notch, CSL and MAML form a tertiary complex which in turn recruites p300 and other coactivators (CoA) to the chromatin and forming the NTC that activates transcription. The NTC can form heterodimers on the chromatin with other NTCs or supramolecular complexes with other transcription factors, modulating the choice of genes regulated by Notch. Dominant negative (DN) MAML constructs or peptidomimetic agents have been used in vivo to inhibit Notch-mediated transcriptional activation (see reference 5 for review).

\section{Role of Notch during embryonic vascular development}

Vascular development is modulated by Notch signaling, which is active in both endothelial and smooth muscle cells. In particular, endothelial cells express Notch receptors 1, -2 and -4 and ligands Jagged1, DLL4 and DLL1 while vascular smooth muscle cells (VSC) are characterized by Notch3 expression. [ 9, 10]. During embryonic development, Notch induces differentiation of angioblasts to endothelial cells, and controls cell fate specification of endothelial cells into arterial or venous identities [11]. Mouse embryos with Notch1 loss of function or double Notch1 and Notch4 loss of function mutations display severe defects in vascular development [ 12]. Endothelial-specific knockout of Jagged1 results in an embryonic lethal phenotype with absence of smooth muscle actin [ 13]. Loss of Notch3 produces dilated arteries with abnormal elastic laminae [ 14] Mice homozygous for Jagged1 loss of function mutation die from haemorrhage early during development [ 15]. Consistently with the major role played by Notch during vascular development, two human cardiovascular diseases are associated with genetic alterations of this pathway. Mutations of Notch3 cause CADASIL ( Cerebral Autosomal- Dominant Artheriopathy with Subcortical Infarcts and Leukoencephalopathy), characterised by stroke and dementia due to vascular lesions [ 16]. Alagille syndrome is a pleiotropic developmental disease caused by mutations of Jagged1 and characterized by congenital heart defect with cardiovascular anomalies [ 17]. 


\title{
Role of Notch in vascular homeostasis and function during postnatal life
}

\author{
Ischemic tissues and tumor angiogenesis
}

Angiogenesis requires stimulation of vascular endothelial cells through the release of angiogenic factors. Of these, vascular endothelial growth factor A (VEGF-A) is the most critical regulator of vascular development [ 18]. VEGFR2 regulates most of the endothelial cell response to VEGF-A, including cell migration, proliferation, survival, permeability and sprouting of new blood vessels from pre-existing ones [ 19]. Sprouting begins with VEGF-A induction of filopodia on specialized endothelial cells, the "tip" cells, which are guided by a gradient of VEGF-A [ 20]. For productive angiogenesis, branching must be limited to "tip" cells and simultaneously inhibited in the adjacent cells, known as "stalk" cells, characterized by lack of protrusive activity. Endothelial cells dynamically compete for the "tip" cell position, and the selection between "tip"- and "stalk" cell fate depends on the interplay between VEGF and Notch pathways which interact at several levels to generate a highly organized blood vessel network [21]. According to a model supported by a wealth of experimental data, VEGF-A induces expression of DLL4 in endothelial "tip" cells [ 22], which in turn activates Notch on the adjacent endothelial cells dampening their response to VEGF-A and conferring a "stalk" phenotype [ 23]. Notch activation in human umbilical vein cells (HUVEC) decreases their response to VEGF-A through downregulation of VEGFR-2 (Taylor 372-383) and upregulation of VEGFR-1, a VEGFR isoform with weak tyrosine kinase activity [ 24-26]. VEGFR-1 regulates sprout formation also by production of sFlt-1, a soluble form of VEGFR-1 that antagonizes VEGF signaling [ 27, 28]. Directionality of the guided sprouting process is thus achieved through a population behavior, in which the migration influenced by the VEGFR-DLL4-Notch interplay, continues toward the highest concentration of VEGF-A [ 29]. This phenomenon is reminiscent of classical "lateral inhibition" during Drosophila neurogenesis. Ectodermal cells differentiating towards a neuronal fate prevent adjacent cells from undergoing the same fate by expressing Notch ligand Delta and activating Notch in adjacent cells [6].

Consistently with the model described above, blockade of DLL4 with specific monoclonal antibodies in experimental tumors leads to excessive branching and unproductive angiogenesis [ 30]. Similarly, inhibition of DLL4 signaling by intramuscular injection of an adenovirus encoding a soluble form of DLL4 extracellular domain impairs reparative angiogenesis in a mouse model of ischemia [31].

$\mathrm{N}$-acetyl-glucosaminidation of fucose residues on the extracellular subunit of Notch, catalyzed by enzymes of the Fringe family, affects differentially Notch activation induced by Jagged or Delta-family ligands [ 32]. In particular, Fringe glycosylation, even though it does not reduce Jagged1 binding to Notch1, potentiates DLL1 over Jagged 1 signaling, probably by a more effective promotion of Notch proteolysis following ligand binding [ 33]. Benedito et al. have shown that in presence of glycosylated Notch, high levels of Jagged1 in endothelial cells inhibit DLL4 signaling, leading to enhanced sprouting and promotion of angiogenesis [ 34]. Tumor necrosis factor $\alpha(\mathrm{TNF} \alpha)$, a cytokine abundant in many solid tumors, induces Jagged 1 in endothelial cells, conferring a "tip" cell phenotype highly enriched in Jagged1, but not DLL4 [ 35]. Taken together, these findings indicate that the effects of Notch signaling on angiogenesis are also controlled by the relative expression levels of DLL4 and Jagged1 ligands, and by the relative affinity of Notch receptors for these classes of ligands, which in turn is dependent on Fringe-catalyzed Notch modifications. Factors that selectively control the expression of the two ligands DLL4 or Jagged1, or modulate the affinity of receptors for these ligands, could have a profound influence on tumor angiogenesis.

Lymphangiogenesis may be as important to tumor biology as hemangiogenesis, particularly for tumors that predominantly metastasize to regional lymph nodes. VEGFR-3 is expressed on lymphatic endothelium and with its ligand VEGF-C, stimulates the growth of lymphatic vessels, regulating physiological and pathological lymphangiogenesis [ 36] as well as embryonic angiogenesis before the emergence of lymphatic vessels [ 37]. In breast cancer, VEGFR-3 expression is upregulated in the endothelium of tumor blood vessels, while VEGF$\mathrm{C}$ is highly expressed in intraductal and invasive cancer cells [ 38]. Notch induces VEGFR-3 expression in human endothelial cells and in mice, increasing endothelial cell responsiveness to VEGF-C and promoting endothelial cell survival and morphological changes [ 39]. Notch1 and Notch4 are expressed in normal and tumor lymphatic endothelial cells, and Notch1 is activated in lymphatic endothelium of invasive mammary micropapillary carcinomas [ 39] These data suggest a role for cross-talk between VEGFR-3 and Notch in both tumor angiogenesis and lymphangiogenesis.

\section{Regulation of bone marrow endothelial progenitor cells}

New blood vessels formation in tumors is thought to happen through two processes: angiogenesis, defined as the proliferation and sprouting of existing blood vessels, and vasculogenesis, resulting from the recruitment of circulating cells derived from the bone marrow [40]. Endothelial progenitor cells (EPC) are an important fraction of bone-marrow derived cells in addition to myeloid cells, lymphocytes, and mesenchymal cells. Studies conducted in Jagged1-null mice have demonstrated that Jagged1 activation of Notch signaling is 
required for EPC development [ 41]. Compared to wild-type animals, Jagged1 null mice show a lower number of endothelium-specific markers expressing cells and EPC colony-forming cells [ 41]. Specific inactivation of Jagged1-mediated Notch signals led to inhibition of postnatal vasculogenesis in hind-limb ischemia via impairment of proliferation, survival, differentiation, and mobilization of bone marrow-derived EPCs.

Recovery of hind-limb perfusion was enhanced after transplantation of Jagged1-stimulated EPCs [ 41]. One of the mechanisms by which activation of Notch signaling enhances mobilization and homing of EPC to neovascularization sites may be the regulation of CXCR4 expression. CXCR4 is the receptor for stromal derived factor 1 (SDF-1), a cytokine induced by hypoxia and involved in EPC homing [ 42]. CSL (RBP-J $)$ deficient EPC from knockout mice have decreased ability to adhere, migrate, and form vessel-like structures in three-dimensional cultures. Over-expression of CXCR4 can rescue these defects [ 43]. Further evidence showing the critical role played by Notch signaling in endothelial cell maturation comes from experiments with cholesterol-lowering statins. These drugs, as a result of a pleiotropic effect, promote endothelial differentiation in bone marrow stem cells (BMSC) [ 44]. Simvastatin promotes the expression of endothelial markers and endothelial differentiation in BMSC. This effect can be prevented by either a $\gamma$-secretase inhibitor (GSI) or Notch1 siRNA. These data suggest that Notch1 and Jagged1 may play an important role in EPC generation and homing to tumors.

\section{Regulation of endothelial cell apoptosis}

TNF $\alpha$, a cytokine abundant in many solid tumors, cross-talks with Notch signaling in controlling endothelial cell apoptosis. In endothelial cells, TNFo treatment downregulates Notch4 mRNA and upregulates Notch2 mRNA. These changes are associated with a decrease of Notch activity, as indicated by reduced levels of Hey2 and Hes1 mRNA [ 45]. TNF $\alpha$-mediated Notch inhibition is associated with endothelial cells apoptosis, as shown by caspase 3 activation in endothelial cells of lung sections from rats treated with TNF $\alpha$. [ 45]. Since overexpression of Notch2 in endothelial cells decreases the levels of survivin, a key antiapoptotic factor, it has been suggested that TNF $\alpha$ signaling sensitizes endothelial cells to apoptosis by activating Notch 2 and thus decreasing Notch activity [ 46]. Conversely, constitutively active Notch4 protects endothelial cells from apoptosis by increasing the levels of Bcl-2 [ 47]. Pulsatile flow promotes bovine retinal endothelial cells survival through Notch1 mediated upregulation of Bcl2 and Bax mRNA levels [ 48]. Notch signaling is also implicated in the pro-survival action of VEGF-A on endothelial cells. GSIs block the anti-apoptotic effect of VEGF-A on endothelial cells exposed to serum deprivation [ 49]. Additionally, Notch1 induces VEGFR-3 expression, which responds to VEGF-C promoting endothelial cells survival [ 39]. Thus, in addition to modulating angiogenesis and vasculogenesis, Notch signaling may control the survival of endothelial cells in tumors.

\section{Endothelial cells, Notch signaling and the CSC "niche"}

It is becoming widely accepted that many solid tumors contain relatively rare sub-populations of cells called cancer stem-like cells (CSC), with properties similar to those of normal tissue stem cells. While the origin of these cells is controversial, there is increasing evidence that these cells are more resistant than "bulk" cancer cells to conventional therapeutic modalities and that they may be at the origin of tumor recurrence and metastasis [ 50]. The Notch pathway is critical in controlling the fate of CSC from several tumors and a variety of therapeutic agents targeting Notch signaling in these cells are being developed [ 50]. The widest experimental support to date for a role of Notch in CSC comes from studies in breast cancer [ 51- 55], embryonal brain tumors [ 56], and gliomas [ 57, 58]. Notch paralogs (1, 3 and 4) modulate breast CSC activity, with the strongest evidence favoring Notch4 [ 59,60]. Inhibition of Notch4 has been shown to reduce stem cell activity [ 61,62]. GSIs abolish the formation of secondary mammospheres from a variety of human breast cancer cell lines as well as patient specimens [ 63]. GSIs in combination with trastuzumab (Herceptin) abolish recurrence of Her2/Neu positive xenografts [ 64]. Since GSIs alone do not decrease tumor volume in this model, while trastuzumab alone drastically decreases tumor volume but does not prevent recurrence, the curative effects of GSIs most likely results from an anti-CSC effect.

The stem-like phenotype of CSC, like the stem phenotype of normal tissue stem cells, is controlled by microenvironmental signals. Endothelial cells are a major component of the CSC microenvironment, sometimes defined as a "vascular niche". It has been suggested that endothelial cells control the homeostasis of CSC by releasing stem cell-active trophogens or by direct cellular contacts (reviewed in [2]). Evidence for a role of Notch in endothelial control of CSC has been obtained in glioblastoma multiforme (GBM). In threedimensional explants of GBM, Notch inhibition blocks the self-renewal of GBM CSC by decreasing the number of endothelial cells [ 65]. Conversely, CSC can stimulate angiogenesis, at least in part by producing VEGF [ 66- 69]. Hypoxia has been suggested to play an important role in maintaining the CSC niche [ 70]. Hypoxia activates Notch signalling via HIF-1 $\alpha$ in normal embryonic stem cells [ 71] and lung cancer cells [ 
72], and mediates the effects of hypoxia on cancer cell fate determination in several models [ 73, 74]. Thus, partially effective anti-angiogenic therapy, by inducing hypoxia may actually activate Notch and preserve CSC. Another facet of the endothelium/CSC interplay is the possibility that endothelial cells may be produced from trans-differentiation of CSC, a phenomenon known as vascular mimicry. This phenomenon was originally described in melanoma [ 75,76$]$ and subsequently found in several other malignancies. Recent evidence indicates that glioma CSC are capable of vascular mimicry under hypoxic conditions [ 77], and that a significant fraction of GBM endothelial cells are derived from the tumor rather than from normal, pre-existing capillaries. A role for Notch in modulating the cell fate decisions underlying vascular mimicry has been proposed in melanoma [ 75] but remains poorly understood.

Cells involved in immunity and inflammation in tumor microenvironment can potentially affect both angiogenesis and CSC. Angiogenesis and immune responses are inextricably linked [ 78-81]. Proinflammatory Th17-cells, interconvertible with Th1 cells, play a crucial and complex role in tumorigenesis [ 79]. Tumor-infiltrating lymphocytes from human breast, ovarian and colorectal cancers contain high numbers of Th17 cells, attracted by RANTES and MCP-1 produced by tumor cells and stroma [ 79]. Th17 polarization requires IL-6 and IL-23, and Th17 cells produce IL-17, which stimulates angiogenesis [ 82, 83], invasion [ 84] and production of pro-angiogenic IL-8 [ 85]. IL-6 and IL-8 have been reported to cause resistance to RO4929097 GSI [ 86, 87]. IL-6 is a Notch target gene in tumor stroma in multiple myeloma [ 88] The Osborne lab in collaboration with us has shown that Notch signaling is required for the generation of Th1 [ 89] and Th17 [ 90] CD4 cells in vitro and in vivo and that GSIs inhibit Th17 lineage determination [91]. In addition to Th17 cells, other immune cell types can modulate the CSC niche, either directly or through endothelial cells. Recent evidence [ 92] shows that macrophage-derived VEGF-C activates VEGFR-3 in endothelial tip cells during lymphangiogenesis. VEGFR3 in turn activates Notch signaling, which promotes the phenotypic conversion of endothelial cells at fusion points of vessel sprouts. Hence, the CSC niche not only relies on endothelial cells but can itself modulate angiogenesis not only through VEGF production by cancer cells but through pro-angiogenic cytokines produced by tumor-infiltrating lymphocytes and macrophages. Tumor-associated fibroblasts also produce a variety of pro-angiogenic cytokines that modulate endothelial cell fate in the CSC niche (reviewed in [93]). The Notch pathway participates in regulating endothelial cell fate, CSC cell fate and Th17 cell fate determination, and thus plays a central role in this complex interplay. Figure 2 shows a schematic representation of these cellular interactions. Figure 2

Selected cellular interactions within the CSC niche: Endothelial cells (EC) specialize into "tip" EC, which respond to VEGF-A signals by expressing DLL4 and activating Notch in "stalk" EC, where Notch prevents further branching. Notch-ligand interactions are represented by intercellular receptor-ligand pairs (see inset). Notch-ligand interactions can occur between tip EC and stalk EC, between CC and EC, between CSC and EC. Blood and lymphatic EC contribute to the CSC niche by providing trophic factors and ligand-Notch interactions. Non-stem cancer cells (CC) produce VEGF-A as well as numerous cytokines, including IL-8, IL6 , TNF $\alpha$, MCP-1, TGF- $\beta$ and RANTES. VEGF-A activates angiogenesis and has autocrine effects on cancer cells. Some cytokines (e.g., IL-8) act on EC directly, while others (e.g., IL-6, MCP-1) recruit pro-inflammatory Th17 cells. These are stimulated by IL-23 and produce IL-17, which stimulates angiogenesis. TAM produce cytokines (not shown) and VEGF-C. The latter activates VEGFR-3 in EC, stimulating Notch activity and inhibiting further branching in the context of lymphangiogenesis. Additional cells not shown in this diagram include fibroblasts, osteoclasts (in bone metastastases), bone marrow stromal cells, NK cells and others.

\section{Therapeutic implications of the cross-talk between Notch and pro-angiogenic factors in cancer}

The role of Notch signaling in controlling the survival of cancer cells is well established and small molecule GSI are currently being tested in several phase 1 and 2 clinical trials in breast, lung cancer and leukemia with relatively minimal toxicity when administered intermittently [94]. We have recently concluded a pilot trial in ER+ breast cancer, where doses of GSI that did not cause significant systemic toxicity were shown to affect the expression of Notch targets and multiple CSC pathways in tumor samples [95]. Notch inhibition may block cancer growth by inhibiting the survival of both "bulk" cancer cells and CSC [ 5]. Cao et al. have shown that treatment with VEGF-A and GSI DAPT can re-establish responsiveness of endothelial cells to VEGF-A [ 96]. This implies that single-agent Notch inhibition, especially at non-cytotoxic doses, may paradoxically increase endothelial responsiveness to VEGF-A. Hypoxia, which is a likely result of VEGF inhibition, can activate Notch signaling through HIF-1 $\alpha$ [ 72, 74], thus potentially protecting endothelial cells from apoptosis and maintaining the integrity of existing tumor vessels, which could resume angiogenesis once VEGF inhibition is relieved. Combinations of Notch inhibitors with VEGF signaling inhibitors may provide superior antiangiogenic activity to single-agent VEGF inhibition and deserve further study. Prolonged administration and/or 
high doses of GSI may be sufficient to cause endothelial apoptosis, but may be less well tolerated than lower doses or intermittent administration in combination with a VEGF inhibitor.

VEGF receptors are expressed in some human breast cancer cells and VEGF directly stimulates breast cancer progression via autocrine signaling [ 97, 98]. We have recently reported that VEGFR-1 and -2 are expressed in a mouse ER $\alpha$-positive breast cancer cell line [99, 100] and that VEGF-A and VEGFRs 1and 2 are highly expressed in triple-negative breast cancer cells compared to ER $\alpha$-positive breast cancer cells [ 100]. Additionally we confirmed that paracrine effects (especially angiogenesis) and autocrine effects (proliferation and migration) of VEGF contribute to breast cancer progression [ 100]. Sunitinib (SU11248), an inhibitor of protein kinases including VEGFRs 1-3, inhibits both paracrine and autocrine effects of VEGF, targeting not only the tumor vasculature but also directly inhibiting the proliferation and migration breast cancer cells in vitro and in vivo [ 100]. The combination of VEGF and Notch inhibitors in the treatment of breast cancer is under investigation in our lab.

\section{Concluding remarks and future directions}

The studies presented in this review strongly suggest that angiogenic and stem cell pathways are inextricably connected in tumor microenvironment, and that the interplay between Notch and VEGF signals plays a central role in regulating cell fate within endothelial cells and CSC, as well as interactions between endothelium and CSC (Figure 2). Additionally, the role Notch-dependent pro-inflammatory Th17 cells and the role of TAM in modulating endothelial cell fate in the CSC niche requires careful investigation. Using Notch inhibitors in combination with anti angiogenic drugs in oncology could introduce a new approach to the prevention of cancer progression and recurrence by delivering synergistic anti-angiogenic effects while disrupting the CSC niche.

\section{Declarations}

\section{Authors' original submitted files for images}

Below are the links to the authors' original submitted files for images.

Authors' original file for figure 1

Authors' original file for figure 2

Authors' original file for figure 3

\section{Competing interests}

The authors declare that they have no competing interests.

\section{Authors' contributions}

JG reviewed the literature on tumor angiogenesis. AP reviewed the literature on cancer stem cells. PR reviewed the literature on normal endothelial and mesenchymal stem cells. BAO reviewed the literature on Th17, Th1 and tumor-associated macrophages; TEG reviewed the literature on gamma-secretase inhibitors. LM edited all author contributions, prepared the final manuscripts and drew the illustrations.

\section{References}

1. Chiu JJ, Chien S. Effects of disturbed flow on vascular endothelium: pathophysiological basis and clinical perspectives. Physiol Rev. 2011;91:327-387.

View Article Google Scholar

2. Butler JM Kobayashi H Rafii S Instructive role of the vascular niche in promoting tumour growth and tissue repair by angiocrine factors Nat Rev Cancer 2010101381462944775

3. Hofer E Schweighofer B Signal transduction induced in endothelial cells by growth factor receptors involved in angiogenesis Thromb Haemost 2007973553632879321 
4. Kume T Novel insights into the differential functions of Notch ligands in vascular formation $\mathrm{J}$ Angiogenes Res 2009182794854

5. Pannuti A Foreman K Rizzo P Osipo C Golde T Osborne B Targeting Notch to target cancer stem cells Clin Cancer Res 201016314131523008160

6. Artavanis-Tsakonas S, Rand MD, Lake RJ. Notch signaling: cell fate control and signal integration in development. Science. 1999;284:770-776.

View Article Google Scholar

7. Kopan R Ilagan MX The canonical Notch signaling pathway: unfolding the activation mechanism Cell 20091372162332827930

8. Miele L. Notch signaling. Clin Cancer Res. 2006;12:1074-1079.

View Article Google Scholar

9. Hofmann JJ, Iruela-Arispe ML. Notch signaling in blood vessels: who is talking to whom about what?. Circ Res. 2007;100:1556-1568.

View Article Google Scholar

10. Villa N, Walker L, Lindsell CE, Gasson J, Iruela-Arispe ML, Weinmaster G. Vascular expression of Notch pathway receptors and ligands is restricted to arterial vessels. Mech Dev. 2001;108:161164.

View Article Google Scholar

11. Al Haj ZA, Madeddu P. Notch signalling in ischaemia-induced angiogenesis. Biochem Soc Trans. 2009;37:1221-1227.

View Article Google Scholar

12. Krebs LT Xue Y Norton CR Shutter JR Maguire M Sundberg JP Notch signaling is essential for vascular morphogenesis in mice Genes Dev 20001413431352316662

13. High FA Lu MM Pear WS Loomes KM Kaestner KH Epstein JA Endothelial expression of the Notch ligand Jagged1 is required for vascular smooth muscle development Proc Natl Acad Sci USA 2008105195519592538864

14. Domenga V Fardoux P Lacombe P Monet M Maciazek J Krebs LT Notch3 is required for arterial identity and maturation of vascular smooth muscle cells Genes Dev 2004182730 2735528893

15. Xue Y, Gao X, Lindsell CE, Norton CR, Chang B, Hicks C, et al. Embryonic lethality and vascular defects in mice lacking the Notch ligand Jagged1. Hum Mol Genet. 1999;8:723-730.

View Article Google Scholar

16. Joutel A, Corpechot C, Ducros A, Vahedi K, Chabriat H, Mouton P, et al. Notch3 mutations in CADASIL, a hereditary adult-onset condition causing stroke and dementia. Nature. 1996;383:707-710.

View Article Google Scholar

17. Iso T, Hamamori Y, Kedes L. Notch signaling in vascular development. Arterioscler Thromb Vasc Biol. 2003;23:543-553.

View Article Google Scholar

18. Ferrara N. Vascular endothelial growth factor: basic science and clinical progress. Endocr Rev. 2004:25:581-611.

View Article Google Scholar

19. Olsson AK, Dimberg A, Kreuger J, Claesson-Welsh L. VEGF receptor signalling - in control of vascular function. Nat Rev Mol Cell Biol. 2006;7:359-371. 
20. Gerhardt H Golding M Fruttiger M Ruhrberg C Lundkvist A Abramsson A VEGF guides angiogenic sprouting utilizing endothelial tip cell filopodia J Cell Biol 20031611163 11772172999

21. Thurston G Kitajewski J VEGF and Delta-Notch: interacting signalling pathways in tumour angiogenesis Br J Cancer 200899120412092570514

22. Liu ZJ Shirakawa T Li Y Soma A Oka M Dotto GP Regulation of Notch1 and Dll4 by vascular endothelial growth factor in arterial endothelial cells: implications for modulating arteriogenesis and angiogenesis Mol Cell Biol 2003231425140667

23. Roca C, Adams RH. Regulation of vascular morphogenesis by Notch signaling. Genes Dev. 2007;21:2511-2524.

View Article Google Scholar

24. Funahashi Y Shawber CJ Vorontchikhina M Sharma A Outtz HH Kitajewski J Notch regulates the angiogenic response via induction of VEGFR-1 J Angiogenes Res 2010232828996

25. Funahashi Y Shawber CJ Sharma A Kanamaru E Choi YK Kitajewski J Notch modulates VEGF action in endothelial cells by inducing Matrix Metalloprotease activity Vasc Cell 20113 23039832

26. Harrington LS, Sainson RC, Williams CK, Taylor JM, Shi W, Li JL, et al. Regulation of multiple angiogenic pathways by Dll4 and Notch in human umbilical vein endothelial cells. Microvasc Res. 2008;75:144-154.

View Article Google Scholar

27. Kappas NC Zeng G Chappell JC Kearney JB Hazarika S Kallianos KG The VEGF receptor Flt1 spatially modulates Flk-1 signaling and blood vessel branching J Cell Biol 2008181847 8582396811

28. Kearney JB, Kappas NC, Ellerstrom C, DiPaola FW, Bautch VL. The VEGF receptor flt-1 (VEGFR1 ) is a positive modulator of vascular sprout formation and branching morphogenesis. Blood. 2004; 103:4527-4535.

View Article Google Scholar

29. Jakobsson L, Franco CA, Bentley K, Collins RT, Ponsioen B, Aspalter IM, et al. Endothelial cells dynamically compete for the tip cell position during angiogenic sprouting. Nat Cell Biol. 2010;12:943-953.

View Article Google Scholar

30. Hoey T, Yen WC, Axelrod F, Basi J, Donigian L, Dylla S, et al. DLL4 blockade inhibits tumor growth and reduces tumor-initiating cell frequency. Cell Stem Cell. 2009;5:168-177.

View Article Google Scholar

31. Al Haj ZA, Oikawa A, Bazan-Peregrino M, Meloni M, Emanueli C, Madeddu P. Inhibition of deltalike-4-mediated signaling impairs reparative angiogenesis after ischemia. Circ Res. 2010;107:283-293.

View Article Google Scholar

32. D'Souza B Miyamoto A Weinmaster G The many facets of Notch ligands Oncogene 200827 514851672791526

33. Yang LT Nichols JT Yao C Manilay JO Robey EA Weinmaster G Fringe glycosyltransferases differentially modulate Notch1 proteolysis induced by Delta1 and Jagged1 Mol Biol Cell 2005 16927942545923 
34. Benedito R, Roca C, Sorensen I, Adams S, Gossler A, Fruttiger M, et al. The notch ligands Dll4 and Jagged1 have opposing effects on angiogenesis. Cell. 2009;137:1124-1135.

View Article Google Scholar

35. Sainson RC Johnston DA Chu HC Holderfield MT Nakatsu MN Crampton SP TNF primes endothelial cells for angiogenic sprouting by inducing a tip cell phenotype Blood 2008111 499750072384130

36. Witmer AN, van Blijswijk BC, Dai J, Hofman P, Partanen TA, Vrensen GF, et al. VEGFR-3 in adult angiogenesis. J Pathol. 2001;195:490-497.

View Article Google Scholar

37. Dumont DJ, Jussila L, Taipale J, Lymboussaki A, Mustonen T, Pajusola K, et al. Cardiovascular failure in mouse embryos deficient in VEGF receptor-3. Science. 1998;282:946-949.

View Article Google Scholar

38. Valtola R Salven P Heikkila P Taipale J Joensuu H Rehn M VEGFR-3 and its ligand VEGF-C are associated with angiogenesis in breast cancer Am J Pathol 1999154138113901866582

39. Shawber CJ Funahashi Y Francisco E Vorontchikhina M Kitamura Y Stowell SA Notch alters VEGF responsiveness in human and murine endothelial cells by direct regulation of VEGFR-3 expression J Clin Invest 2007117336933822030453

40. Ahn GO Brown JM Role of endothelial progenitors and other bone marrow-derived cells in the development of the tumor vasculature Angiogenesis 2009121591642863022

41. Kwon SM, Eguchi M, Wada M, Iwami Y, Hozumi K, Iwaguro H, et al. Specific Jagged-1 signal from bone marrow microenvironment is required for endothelial progenitor cell development for neovascularization. Circulation. 2008;118:157-165.

View Article Google Scholar

42. Ceradini DJ, Gurtner GC. Homing to hypoxia: HIF-1 as a mediator of progenitor cell recruitment to injured tissue. Trends Cardiovasc Med. 2005;15:57-63.

View Article Google Scholar

43. Wang L Wang YC Hu XB Zhang BF Dou GR He F Notch-RBP-J signaling regulates the mobilization and function of endothelial progenitor cells by dynamic modulation of CXCR4 expression in mice PLoS One 20094 e75722762521

44. Xu J Liu X Chen J Zacharek A Cui X Savant-Bhonsale S Simvastatin enhances bone marrow stromal cell differentiation into endothelial cells via notch signaling pathway Am J Physiol Cell Physiol 2009296 C535 C5432660258

45. Quillard T, Devalliere J, Coupel S, Charreau B. Inflammation dysregulates Notch signaling in endothelial cells: implication of Notch2 and Notch4 to endothelial dysfunction. Biochem Pharmacol. 2010;80:2032-2041.

View Article Google Scholar

46. Quillard T Devalliere J Chatelais M Coulon F Seveno C Romagnoli M Notch2 signaling sensitizes endothelial cells to apoptosis by negatively regulating the key protective molecule survivin PLoS One 20094 e82442785888

47. MacKenzie F, Duriez P, Wong F, Noseda M, Karsan A. Notch4 inhibits endothelial apoptosis via RBP-Jkappa-dependent and -independent pathways. J Biol Chem. 2004;279:11657-11663.

View Article Google Scholar

48. Walshe TE, Connell P, Cryan L, Ferguson G, Gardiner T, Morrow D, et al. Microvascular retinal endothelial and pericyte cell apoptosis in vitro: role of Hedgehog and Notch signaling. Invest 
49. Takeshita K Satoh M Ii M Silver M Limbourg FP Mukai Y Critical role of endothelial Notch1 signaling in postnatal angiogenesis Circ Res 200710070782615564

50. Pannuti A Foreman K Rizzo P Osipo C Golde T Osborne B Targeting Notch to target cancer stem cells Clin Cancer Res 201016314131523008160

51. Farnie G, Clarke RB. Mammary stem cells and breast cancer-role of Notch signalling. Stem Cell Rev. 2007;3:169-175.

View Article Google Scholar

52. Farnie G, Clarke RB, Spence K, Pinnock N, Brennan K, Anderson NG, et al. Novel cell culture technique for primary ductal carcinoma in situ: role of Notch and epidermal growth factor receptor signaling pathways. J Natl Cancer Inst. 2007;99:616-627.

View Article Google Scholar

53. Sansone P, Storci G, Giovannini C, Pandolfi S, Pianetti S, Taffurelli M, et al. p66Shc/Notch-3 interplay controls self-renewal and hypoxia survival in human stem/progenitor cells of the mammary gland expanded in vitro as mammospheres. Stem Cells. 2007;25:807-815 .

View Article Google Scholar

54. Kakarala M, Wicha MS. Cancer stem cells: implications for cancer treatment and prevention. Cancer J. 2007;13:271-275.

View Article Google Scholar

55. Korkaya H, Wicha MS. Selective targeting of cancer stem cells: a new concept in cancer therapeutics. BioDrugs. 2007;21:299-310.

View Article Google Scholar

56. Fan X, Matsui W, Khaki L, Stearns D, Chun J, Li YM, et al. Notch pathway inhibition depletes stemlike cells and blocks engraftment in embryonal brain tumors. Cancer Res. 2006;66:7445-7452. View Article Google Scholar

57. Fan X Khaki L Zhu TS Soules ME Talsma CE Gul N Notch pathway blockade depletes cd133positive glioblastoma cells and inhibits growth of tumor neurospheres and xenografts Stem Cells 2010285162878196

58. Wang J Wakeman TP Lathia JD Hjelmeland AB Wang XF White RR Notch promotes radioresistance of glioma stem cells Stem Cells 20102817282825687

59. Harrison H Farnie G Howell SJ Rock RE Stylianou S Brennan KR Regulation of breast cancer stem cell activity by signaling through the Notch4 receptor Cancer Res 201070709 7183442245

60. Harrison H, Farnie G, Brennan KR, Clarke RB. Breast cancer stem cells: something out of notching?. Cancer Res. 2010;70:8973-8976.

View Article Google Scholar

61. Dontu G Jackson KW McNicholas E Kawamura MJ Abdallah WM Wicha MS Role of Notch signaling in cell-fate determination of human mammary stem/progenitor cells Breast Cancer Res 20046 R605 R6151064073

62. Raouf A, Zhao Y, To K, Stingl J, Delaney A, Barbara M, et al. Transcriptome analysis of the normal human mammary cell commitment and differentiation process. Cell Stem Cell. 2008;3:109-118. 
63. Grudzien P, Lo S, Albain KS, Robinson P, Rajan P, Strack PR, et al. Inhibition of Notch signaling reduces the stem-like population of breast cancer cells and prevents mammosphere formation. Anticancer Res. 2010;30:3853-3867.

View Article Google Scholar

64. Pandya K Meeke K Clementz AG Rogowski A Roberts J Miele L Targeting both Notch and ErbB-2 signalling pathways is required for prevention of ErbB-2-positive breast tumour recurrence Br J Cancer 20111057968063171020

65. Hovinga KE, Shimizu F, Wang R, Panagiotakos G, Van Der Heijden M, Moayedpardazi H, et al. Inhibition of notch signaling in glioblastoma targets cancer stem cells via an endothelial cell intermediate. Stem Cells. 2010;28:1019-1029.

View Article Google Scholar

66. Bao S, Wu Q, Sathornsumetee S, Hao Y, Li Z, Hjelmeland AB, et al. Stem cell-like glioma cells promote tumor angiogenesis through vascular endothelial growth factor. Cancer Res. 2006;66:7843-7848.

View Article Google Scholar

67. Calabrese C, Poppleton H, Kocak M, Hogg TL, Fuller C, Hamner B, et al. A perivascular niche for brain tumor stem cells. Cancer Cell. 2007;11:69-82.

View Article Google Scholar

68. Folkins C Shaked Y Man S Tang T Lee CR Zhu Z Glioma tumor stem-like cells promote tumor angiogenesis and vasculogenesis via vascular endothelial growth factor and stromal-derived factor 1 Cancer Res 200969724372513409689

69. Gilbertson RJ, Rich JN. Making a tumour's bed: glioblastoma stem cells and the vascular niche. Nat Rev Cancer. 2007;7:733-736.

View Article Google Scholar

70. Seidel S, Garvalov BK, Wirta V, von Stechow L, Schanzer A, Meletis K, et al. A hypoxic niche regulates glioblastoma stem cells through hypoxia inducible factor 2 alpha. Brain. 2010;133:983995.

View Article Google Scholar

71. Gustafsson MV, Zheng X, Pereira T, Gradin K, Jin S, Lundkvist J, et al. Hypoxia requires notch signaling to maintain the undifferentiated cell state. Dev Cell. 2005;9:617-628.

View Article Google Scholar

72. Chen Y, De Marco MA, Graziani I, Gazdar AF, Strack PR, Miele L, et al. Oxygen concentration determines the biological effects of NOTCH-1 signaling in adenocarcinoma of the lung. Cancer Res. 2007;67:7954-7959.

View Article Google Scholar

73. Eliasz S Liang S Chen Y De Marco MA Machek O Skucha S Notch-1 stimulates survival of lung adenocarcinoma cells during hypoxia by activating the IGF-1R pathway Oncogene 2010 29248824982861728

74. Sahlgren C Gustafsson MV Jin S Poellinger L Lendahl U Notch signaling mediates hypoxiainduced tumor cell migration and invasion Proc Natl Acad Sci USA 20081056392 63972359811

75. Hendrix MJ, Seftor RE, Seftor EA, Gruman LM, Lee LM, Nickoloff BJ, et al. Transendothelial function of human metastatic melanoma cells: role of the microenvironment in cell-fate determination. Cancer Res. 2002;62:665-668.

View Article Google Scholar 
76. Hendrix MJ, Seftor EA, Hess AR, Seftor RE. Vasculogenic mimicry and tumour-cell plasticity: lessons from melanoma. Nat Rev Cancer. 2003;3:411-421.

View Article Google Scholar

77. Ricci-Vitiani L, Pallini R, Biffoni M, Todaro M, Invernici G, Cenci T, et al. Tumour vascularization via endothelial differentiation of glioblastoma stem-like cells. Nature. 2010;468:824-828.

View Article Google Scholar

78. Iida T, Iwahashi M, Katsuda M, Ishida K, Nakamori M, Nakamura M, et al. Tumor-infiltrating CD4+ Th17 cells produce IL-17 in tumor microenvironment and promote tumor progression in human gastric cancer. Oncol Rep. 2011;25:1271-1277.

View Article Google Scholar

79. Ji Y, Zhang W. Th17 cells: positive or negative role in tumor?. Cancer Immunol Immunother. 2010;59:979-987.

View Article Google Scholar

80. Kesselring R Thiel A Pries R Trenkle T Wollenberg B Human Th17 cells can be induced through head and neck cancer and have a functional impact on HNSCC development $\mathrm{Br} \mathbf{J}$ Cancer 2010103124512542967064

81. Taflin C Favier B Baudhuin J Savenay A Hemon P Bensussan A Human endothelial cells generate Th17 and regulatory T cells under inflammatory conditions Proc Natl Acad Sci USA 2011108289128963041137

82. Takahashi H, Numasaki M, Lotze MT, Sasaki H. Interleukin-17 enhances bFGF-, HGF- and VEGFinduced growth of vascular endothelial cells. Immunol Lett. 2005;98:189-193.

View Article Google Scholar

83. Numasaki M, Fukushi J, Ono M, Narula SK, Zavodny PJ, Kudo T, et al. Interleukin-17 promotes angiogenesis and tumor growth. Blood. 2003;101:2620-2627.

View Article Google Scholar

84. Zhu X Mulcahy LA Mohammed RA Lee AH Franks HA Kilpatrick L IL-17 expression by breast-cancer-associated macrophages: IL-17 promotes invasiveness of breast cancer cell lines Breast Cancer Res 200810 R952656888

85. Inozume T, Hanada K, Wang QJ, Yang JC. IL-17 secreted by tumor reactive T cells induces IL-8 release by human renal cancer cells. J Immunother. 2009;32:109-117.

View Article Google Scholar

86. He W, Luistro L, Carvajal D, Smith M, Nevins T, Yin X, et al. High tumor levels of IL6 and IL8 abrogate preclinical efficacy of the gamma-secretase inhibitor, RO4929097. Mol Oncol. 2011;5:292-301.

View Article Google Scholar

87. Luistro L, He W, Smith M, Packman K, Vilenchik M, Carvajal D, et al. Preclinical profile of a potent gamma-secretase inhibitor targeting notch signaling with in vivo efficacy and pharmacodynamic properties. Cancer Res. 2009;69:7672-7680.

View Article Google Scholar

88. Houde C, Li Y, Song L, Barton K, Zhang Q, Godwin J, et al. Over-expression of the NOTCH Ligand JAG2 in Malignant Plasma Cells from Multiple Myeloma Patients and Cell Lines. Blood. 2004;104:3697-3704.

View Article Google Scholar

89. Minter LM, Turley DM, Das P, Shin HM, Joshi I, Lawlor RG, et al. Inhibitors of gamma-secretase block in vivo and in vitro T helper type 1 polarization by preventing Notch upregulation of 
Tbx21. Nat Immunol. 2005;6:680-688.

View Article Google Scholar

90. Keerthivasan S Suleiman R Lawlor RG Roderick J Bates T Minter LM Notch signaling regulates mouse and human Th17 differentiation J Immunol 20111876927013131467

91. Jinushi M Chiba S Yoshiyama H Masutomi K Kinoshita I Dosaka-Akita H Tumor-associated macrophages regulate tumorigenicity and anticancer drug responses of cancer stem/initiating cells Proc Natl Acad Sci USA 201110812425124303145680

92. Tammela T Zarkada G Nurmi H Jakobsson L Heinolainen K Tvorogov D VEGFR-3 controls tip to stalk conversion at vessel fusion sites by reinforcing Notch signalling Nat Cell Biol 2011 13120212133261765

93. Cirri P, Chiarugi P. Cancer-associated-fibroblasts and tumour cells: a diabolic liaison driving cancer progression. Cancer Metastasis Rev. 2011;:-.

View Article Google Scholar

94. Takebe N, Harris PJ, Warren RQ, Ivy SP. Targeting cancer stem cells by inhibiting Wnt, Notch, and Hedgehog pathways. Nat Rev Clin Oncol. 2011;8:97-106.

View Article Google Scholar

95. Albain K, Czerlanis C, Zlobin A, Covington KR, Rajan P, Godellas C, et al. Modulation of cancer stem cell biomarkers by the notch inhibitor MK0752 added to endocrine therapy for early stage ER+ breast cancer. Cancer Res. 2011;71:97s- .

View Article Google Scholar

96. Cao L Arany PR Wang YS Mooney DJ Promoting angiogenesis via manipulation of VEGF responsiveness with notch signaling Biomaterials 200930408540932730921

97. Lee TH Seng S Sekine M Hinton C Fu Y Avraham HK Vascular endothelial growth factor mediates intracrine survival in human breast carcinoma cells through internally expressed VEGFR1/FLT1 PLoS Med 20074 e1861885450

98. Brown LF, Berse B, Jackman RW, Tognazzi K, Guidi AJ, Dvorak HF, et al. Expression of vascular permeability factor (vascular endothelial growth factor) and its receptors in breast cancer. Hum Pathol. 1995;26:86-91.

View Article Google Scholar

99. Gu JW, Young E, Busby B, Covington J, Tan W, Johnson JW. Oral administration of pyrrolidine dithiocarbamate (PDTC) inhibits VEGF expression, tumor angiogenesis and growth of breast cancer in female mice. Cancer Biol Ther. 2009;8:514-521.

View Article Google Scholar

100. Young E Miele L Tucker KB Huang M Wells J Gu JW SU11248, a selective tyrosine kinases inhibitor suppresses breast tumor angiogenesis and growth via targeting both tumor vasculature and breast cancer cells Cancer Biol Ther 2010107037113230514

101. Gupta-Rossi N Ortica S Meas-Yedid V Heuss S Moretti J Olivo-Marin JC The adaptorassociated kinase 1, AAK1, is a positive regulator of the Notch pathway J Biol Chem 2011286 18720187303099689 